\title{
Standard Operational Protocols in professional nursing practice: use, weaknesses and potentialities
}

\author{
Protocolos Operacionais Padrão na prática profissional da enfermagem: \\ utilização, fragilidades e potencialidades \\ Protocolos Operacionales Patrón en la práctica profesional de enfermería: \\ utilización, fragilidades y potencialidades
}

\section{Camila Balsero Sales', Andrea Bernardes"I,III, Carmen Silvia Gabriel", Maria de Fátima Paiva Brito', André Almeida de Moura"', Ariane Cristina Barboza Zanetti"l' \\ 'Prefeitura Municipal de Ribeirão Preto, Municipal Health Ribeirão Preto. Ribeirão Preto, São Paulo, Brazil. \\ "Universidade de São Paulo, School of Nursing Ribeirão Preto, \\ Department of General and Specialized Nursing. Ribeirão Preto, São Paulo, Brazil. \\ II' Universidade de São Paulo, School of Nursing Ribeirão Preto, \\ Postgraduate Program in Fundamental Nursing. Ribeirão Preto, São Paulo, Brazil.}

How to cite this article:

Sales CB, Bernardes A, Gabriel CS, Brito MFP, Moura AA, Zanetti ACB. Standard Operational Protocols in professional nursing practice: use, weaknesses and potentialities. Rev Bras Enferm [Internet]. 2018;71(1):126-34. DOI: http://dx.doi.org/10.1590/0034-7167-2016-0621

\section{Submission: 11-23-2016 Approval: 03-24-2017}

\section{ABSTRACT}

Objective: to evaluate the use of Standard Operational Protocols (SOPs) in the professional practice of the nursing team based on the theoretical framework of Donabedian, as well as to identify the weaknesses and potentialities from its implementation. Method: Evaluative research, with quantitative approach performed with nursing professionals working in the Health Units of a city of São Paulo, composed of two stages: document analysis and subsequent application of a questionnaire to nursing professionals. Results: A total of 247 nursing professionals participated and reported changes in the way the interventions were performed. The main weaknesses were the small number of professionals, inadequate physical structure and lack of materials. Among the potentialities were: the standardization of materials and concern of the manager and professional related to patient safety. Conclusion: The reassessment of SOPs is necessary, as well as the adoption of a strategy of permanent education of professionals aiming at improving the quality of care provided.

Descriptors: Quality of Health Care; Clinical Protocols; Nursing; Quality management; Quality Assurance of Health Care.

\section{RESUMO}

Objetivo: avaliar a utilização dos Procedimentos Operacionais Padrão (POP) na prática profissional da equipe de enfermagem, com base no referencial teórico de Donabedian, bem como identificar as fragilidades e potencialidades a partir da sua implantação. Método: Pesquisa avaliativa, com abordagem quantitativa realizada com profissionais de enfermagem atuantes nas Unidades de Saúde de um município paulista, composta por duas etapas: análise documental e posterior aplicação de questionário aos profissionais de enfermagem. Resultados: Participaram 247 profissionais de enfermagem que referiram mudanças na forma de execução das intervenções estudadas. As principais fragilidades apontaram para o número reduzido de profissionais, inadequação da estrutura física e ausência de materiais. Entre as potencialidades destacaram-se: a padronização dos materiais e a preocupação do gestor e do profissional relacionada à segurança do paciente. Conclusão: A reavaliação dos POP é necessária, bem como a adoção da estratégia de educação permanente dos profissionais visando à melhoria da qualidade da assistência prestada.

Descritores: Qualidade da Assistência à Saúde; Protocolos Clínicos; Enfermagem; Gestão da Qualidade; Garantia da Qualidade dos Cuidados de Saúde.

\section{RESUMEN}

Objetivo: Evaluar la utilización de los Procedimientos Operacionales Patrón (POP) en la práctica profesional del equipo de enfermería, con base en el referencial teórico de Donabedian, bien como identificar las fragilidades y potencialidades a partir de su implantación. Método: Pesquisa evaluativa, con abordaje cuantitativa realizada con profesionales de enfermería actuantes en las Unidades de Salud 
de un municipio de São Paulo, compuesta por dos etapas: análisis documental y posterior aplicación de cuestionario a los profesionales de enfermería. Resultados: Participaron 247 profesionales de enfermería que han mencionado cambios en la manera de ejecución de las intervenciones estudiadas. Las principales fragilidades apuntaron para el número reducido de profesionales, inadecuación de la estructura física y ausencia de materiales. Entre las potencialidades se destacaron: la estandarización de los materiales y la preocupación del gestor y del profesional relacionada a la seguridad del paciente. Conclusión: La reevaluación de los POP es necesaria, bien como la adopción de la estrategia de educación permanente de los profesionales visando la mejoría de la cualidad de la asistencia prestada. Descriptores: Cualidad de la Asistencia a la Salud; Protocolos Clínicos; Enfermería; Gestión de Cualidad; Garantía de la Cualidad de los Cuidados de Salude.

\section{CORRESPONDING AUTHOR André Almeida de Moura E-mail: andalmo@usp.br}

\section{INTRODUCTION}

Quality in health services has been the object of much research. At the level of care complexity, both primary and secondary, this concern has also arisen with citations referring to quality in various official documents and definitions in norms, protocols, principles and guidelines that organize the actions and practices, as well as the current technical and scientific knowledge, respecting culturally accepted values ${ }^{(1)}$.

In the health services team, the search for quality has occurred mainly with investments in educational processes. This fact represents a constant fear among nurses, as it is not uncommon for a nursing team to suffer exposure in the media, due to the airing of procedural errors, carelessness and lack of compliance with the health service protocols.

Thus, it is necessary to define standards and increase the culture of quality in nursing services ${ }^{(2)}$, the role of nurses is imperative in implementing strategies so that their team ensures patients receive the desired care.

A managerial tool that nurses can use to improve the quality of care provided is the standardization of nursing interventions via the Standard Operational Protocols (SOPs), which must be built together with their staff, taking into account the reality of the Service and encouraging the improvement of its activities.

The standardization of procedures is considered a current management tool and has been widely studied by nursing. The results of its use demonstrate that it is a modern tool ${ }^{(3)}$ that supports decision making by nurses ${ }^{(4)}$, makes it possible to correct nonconformities ${ }^{(5)}$, allows all workers to provide standard care for the patient in accordance with technical and scientific principles and also contributes to remedy the distortions acquired in practice, while also having an educational purpose ${ }^{(4)}$. In addition, the adoption of care protocols can provide greater satisfaction for both the nursing team and the patient ${ }^{(6)}$, greater safety in performing the procedures and, consequently, greater patient safety, aiming to guarantee a care service free of undesirable variations in final quality ${ }^{(7-8)}$, as well as to implement and control nursing care actions permeated by an integral vision the patient ${ }^{(4)}$.

The health services manager must understand the importance and responsibility in the planning of educational actions with the health professionals at his or her institution, always based on the best scientific evidence. From this perspective, it is clear that Evidence-Based Practice (EBP) is a movement that serves as a link between research results and their practical application, thereby guaranteeing improvement in the quality of care provided to clients and greater visibility of the profession by demonstrating the scientific basis for their care ${ }^{(9)}$.

The theoretical framework adopted in this study is the triad of Structure, Process and Outcome proposed by Donabedian ${ }^{(10)}$ to evaluate health care quality. This model has become the foundation of quality assessment, since it is universally accepted and widely used today, especially in the development of quality standards. The author defines "Structure" as the qualification of service providers, equipment, facilities and administrative systems through which care is delivered; "Process" denotes the components of the assistance provided; and "Outcome" as recovery and restoration of patient functions. The triad also emphasizes the need for valid indicators to measure structure and process, since both can be directly related to the results of the care provided, as well as reliable and easily reproducible measures of quality evaluation ${ }^{(11)}$.

Based on the above, the study aims to evaluate the use of Standard Operational Protocols in the professional practice of the nursing team of a Municipal Health Department of the State of São Paulo, based on the Donabedian theoretical framework ${ }^{(10)}$, as well as to identify the weaknesses and potentialities from its implementation, aiming to answer the guiding questions of the research: Is the nursing team using SOPs in their professional practice? What potentialities and weaknesses have arisen after its implementation?

\section{METHOD}

\section{Ethical aspects}

The project was approved by the Research Ethics Committee of the University of São Paulo at Ribeirão Preto College of Nursing. The subjects were consulted about their interest and availability and signed the Term of Free and Informed Consent, in order to comply with the requirements of Resolution $466 / 2012$ of the National Health Council, which regulates the norms for conducting research involving human beings.

\section{Study design, location and period}

A quantitative and evaluative study was carried out, that consisted of making an ex-post judgment of an intervention using scientific methods, seeking to analyze the relevance, the theoretical foundations, the productivity, the effects and the yield of an intervention, as well as the relations between the intervention and the context in which it takes place, in order to assist the decision-making process ${ }^{(12)}$. 
The research was carried out in 51 health units and in the Samu [Mobile Emergency Health Service] of a Municipal Health Secretary (MHS) in the interior of São Paulo State, Brazil. The work was conducted in two phases: the first, which took place in October 2014, corresponded to the analysis of the documents and printed material filed in the Nursing Division of MHS in order to describe the scenario of SOP deployment. The second phase included the delivery and return of the questionnaire to one of the researchers, from April to June 2015. The health professionals returned the completed questionnaires in a timely manner from only 37 out of the 51 health and Samu units.

\section{Population, inclusion and exclusion criteria}

The research population comprised 1,030 nursing professionals working in the MHS. Of these, subjects who were on leave or health leave during the collection period, nursing professionals from administrative units and those admitted after 2013 were excluded. It was considered necessary to apply the latter criterion so that the nursing professional could present at least two years of contact with the protocols and was therefore able to evaluate their use in work activities. All participants were previously given an explanation on the completion of the questionnaire by one of the researchers. A total of 247 (24\%) professionals from all nursing categories answered and returned the instrument.

\section{Data collection}

The questionnaire used was developed by the authors and submitted to the apparent and content validation by six peers in the area of Nursing Management, with masters or doctoral degrees, and knowledge in the research topic. The peers analyzed the instrument for objectivity, clarity, relevance and precision; it is underscored that all suggested changes were complied with. The instrument was composed of two parts: the first dealt with aspects related to the pndividuals (sociodemographic and related to the profession), while the second part contained specific questions about the use of SOPs and their potentialities and weaknesses apparent after implementation.

\section{Analysis of results and statistics}

The data were analyzed using descriptive statistics. The simple and percentage frequency, mean, standard deviation, median, minimum and maximum were calculated. To evaluate the association between the use of SOPs and the professional category, Fisher's exact test was used. The Mann-Whitney test was used to compare the means of the numerical variables: the number of interventions that were carried out; interventions in which the professional changed the method used; increase in knowledge after the implementation of procedures with SOP issues related to participation, access, use and consultation. The same test was used for the variables related to the day-to-day use of SOPs and consulting SOPs within the previous 12 months. All tests were performed with the significance level of $5 \%(\alpha=0.05)$ and the programs used were the SPSS (Statistical Package for the Social Sciences) version 22.0 and $\mathrm{R}$ ( $\mathrm{R}$ Core Team) version 3.0.2. For the discussion of the results, the theoretical framework of Donabedian health services evaluation ${ }^{(10)}$ was used in conjunction with the relevant literature.

\section{RESULTS}

Standard Operational Protocols implementation scenario

Based on an analysis of the documents and printed material filed in the Nursing Division of MHS, it was possible to construct the scenario of the SOPs implementation. The Nursing Division, in mid-2011, considered the need for standardization of the procedures performed by the nursing team. The fact that they did not have a description of the interventions favored the occurrence of errors. A group was formed composed of nurses from this division, health units and infection commission of the institution. The group began the process of constructing SOPs; at first 14 interventions, for example: nasogastric probe, nasoenteral probe, cystostomy catheterization, bladder catheterization for relief, late vesical catheterization, measurement of vital signs, venipuncture and dressings.

The procedures of each intervention were sent for validation by four nurses of the health units, namely: Emergency Care, Basic Health Unit (BHUs) and Family Health Units (FHUs). The validation was done by means of a form that included seven items: clarity of the objective, applicability of the intervention in the service, materials needed to perform the intervention and availability in the services, clarity and order of the steps to be performed during the procedure, adequacy of the illustrations and/or figures, health professionals authorized to perform the intervention and guidance on record keeping by nursing staff.

After receiving these evaluations, the 14 SOPs were validated and the educational process of the nursing professionals began in March 2012. The 14 interventions were divided into three training cycles with a workload of eight hours each in the months of March, September and December 2012.

Due to the large number of professionals distributed in the 51 Health Units and Mobile Emergency Care Service (Samu), the following were invited to participate in this educational process: four nurses from the District Basic Health Units (DBHUs); eight nurses from Samu; and two nurses and two nursing assistants from the BHUs, FHUs, Ambulatories, Mental Health Services and Specialized Services each. These were given the responsibility for communicating the findings to their respective work teams.

\section{Characterization of the subjects and analysis of the Stan- dard Operational Protocols usage}

Of the 247 workers participating in this study, the majority were female professionals $(87.4 \%)$. The age group with the highest percentage refers to 51 to 60 years, representing $34 \%$ of the interviewees, followed by 41 to 50 years, with a percentage of $30.8 \%$.

Among the professionals that participated in the research, 64 (25.9\%) were nurses, 31 (12.6\%) nursing technicians and 152 $(61.5 \%)$ nursing assistants. As for the professional training time, there was a predominance of 2 to 8 years of training (38.5\%). In terms of the number of instruments completed per type of service to which the respondents belonged, the highest percentage was attributed to FHU professionals (77.7\%), followed by BHUs $(40.4 \%)$ and Samu (16\%). Regarding SOPs training, $89.9 \%$ of nursing professionals participated. Among those who did not 
Table 1 - Association test between the professional category and use of the Standard Operational Protocols in the daily practice and in the previous 12 months, Ribeirão Preto, São Paulo, Brazil, 2015

\begin{tabular}{|c|c|c|c|c|c|c|c|}
\hline & & & \multicolumn{3}{|c|}{ Professional category } & \multirow[b]{2}{*}{ Total } & \multirow[b]{2}{*}{$p$ value } \\
\hline & & & Nurse & $\begin{array}{l}\text { Nursing } \\
\text { technician }\end{array}$ & $\begin{array}{l}\text { Assistant } \\
\text { nurse }\end{array}$ & & \\
\hline \multirow{3}{*}{ Use SOP daily } & Yes & $\mathrm{n}(\%)$ & $64(34.41)$ & $24(12.90)$ & $98(52.69)$ & $186(100)$ & \multirow{3}{*}{0.000} \\
\hline & No & $\mathrm{n}(\%)$ & $0(0.00)$ & $6(11.30)$ & $47(88.70)$ & $53(100)$ & \\
\hline & Total & $\mathrm{n}(\%)$ & $64(26.80)$ & $30(12.60)$ & $145(60.70)$ & $239(100)$ & \\
\hline \multirow{3}{*}{$\begin{array}{l}\text { Consulted SOP } \\
\text { in the previous } \\
12 \text { months }\end{array}$} & Yes & $\mathrm{n}(\%)$ & $59(41.55)$ & $21(14.79)$ & $62(43.66)$ & $142(100)$ & \multirow{3}{*}{0.000} \\
\hline & No & $\mathrm{n}(\%)$ & $4(4.12)$ & $9(9.28)$ & $84(86.60)$ & $97(100)$ & \\
\hline & Total & $\mathrm{n}(\%)$ & $63(26.36)$ & $30(12.55)$ & $146(61.09)$ & $239(100)$ & \\
\hline
\end{tabular}

Note: SOP - Standard Operational Protocols

Table 2 - Frequency and percentage of responses in relation to the interventions that have been carried out in the units and changes in the method of performing them after implementing the Standard Operational Protocols, Ribeirão Preto, São Paulo, Brazil, 2015

\begin{tabular}{lccc}
\hline & $\begin{array}{c}\text { Frequency } \\
\text { performed* }\end{array}$ & \multicolumn{2}{c}{ Modified technique** } \\
\cline { 2 - 4 } \multicolumn{1}{c}{ Intervention } & $\mathbf{n ( \% )}$ & Yes & No \\
& & $\mathbf{n}(\mathbf{\%})$ & $\mathbf{n}(\mathbf{\%})$ \\
\hline Catheterization by cystostomy & $44(17.8)$ & $30(12.1)$ & $205(83.0)$ \\
Intestinal lavage & $23(9.3)$ & $11(4.5)$ & $224(90.7)$ \\
Nasoenteral probe & $19(7.7)$ & $14(5.7)$ & $221(89.5)$ \\
Bladder catheterization relief & $15(6.1)$ & $38(15.4)$ & $197(79.8)$ \\
Bladder catheterization, late & $12(4.9)$ & $55(22.3)$ & $180(72.9)$ \\
Aspiration of the airways & $12(4.9)$ & $31(12.6)$ & $204(82.6)$ \\
Nasogastric probe & $11(4.5)$ & $19(7.7)$ & $216(87.4)$ \\
Tracheostomy Cannula Care & $11(4.5)$ & $35(14.2)$ & $200(81.0)$ \\
Venous puncture & $9(3.6)$ & $53(21.5)$ & $182(73.7)$ \\
Vital signs & $8(3.2)$ & $71(28.7)$ & $164(66.4)$ \\
Dressings & $6(2.4)$ & $55(22.3)$ & $180(72.9)$ \\
Capillary glycosimetry & $5(2.0)$ & $45(18.2)$ & $190(76.9)$ \\
Medication administration & $5(2.0)$ & $38(15.4)$ & $197(79.8)$ \\
Blood collection & $3(1.2)$ & $60(24.3)$ & $175(70.9)$ \\
\hline
\end{tabular}

Note: * 16 professionals did not respond; ** 12 professionals did not respond.

Table 3 - Comparison between the deepening of knowledge and participation of the professionals in the Standard Operational Protocols training and between the performance of interventions after implementing Standard Operational Protocols and their use by the professionals studied, Ribeirão Preto, São Paulo, Brazil, 2015

\begin{tabular}{|c|c|c|c|c|c|c|c|c|}
\hline \multirow{2}{*}{$\begin{array}{l}\text { Deepening of } \\
\text { knowledge }\end{array}$} & & \multicolumn{7}{|c|}{ Participated in the SOP training } \\
\hline & & $\mathbf{n}$ & Min & Median & Mean & Max & $\begin{array}{c}\text { Standard } \\
\text { Deviation }\end{array}$ & $\begin{array}{c}p \\
\text { value }\end{array}$ \\
\hline & Yes & 222 & 0 & 2 & 3.18 & 14 & 4 & $0 \Omega$ \\
\hline & No & 25 & 0 & 0 & 1.6 & 14 & 2.87 & 0.00 \\
\hline \multirow{4}{*}{$\begin{array}{l}\text { Interventions } \\
\text { performed } \\
\text { after SOP }\end{array}$} & & \multicolumn{7}{|c|}{ Professionals who use SOP on a daily basis } \\
\hline & & $\mathbf{n}$ & Min & Median & Mean & Max & $\begin{array}{c}\text { Standard } \\
\text { Deviation }\end{array}$ & $\underset{\text { value }}{p}$ \\
\hline & Yes & 186 & 0 & 0 & 0.77 & 10 & 1.76 & \\
\hline & No & 53 & 0 & 0 & 0.57 & 11 & 2 & \\
\hline
\end{tabular}

Note: SOP - Standard Operational Protocols participate in the training, 11 stated it was not offered in their health unit and seven reported that they were away from work activities in the period. These characteristics are presented in Table 1.

There was a statistically significant difference between the variables "Professional category" and "SOP usage in daily practice", as well as between the variables "Professional category" and "Consultation of SOPs in the last 12 months", indicating the existence of an association between them. It should be highlighted, in Table 2, that nurses were the professionals with the lowest percentage $(4 \%)$ of responses regarding not having consulted SOPs in the last 12 months.

From Table 2, it can be seen that all interventions in the Health Units were performed, with changes, following training related to SOPs, the three cited most were: catheterization by cystostomy, intestinal lavage and nasoenteral catheterization.

Another important aspect is the modification to the technique used to perform interventions. It is reiterated that the most cited changes were: vital signs, blood collection, dressings, venipuncture, capillary glycosimetry and medication administration. These interventions are considered to be "basic" by the teams that work in the health units, however they have singular importance for the Health Programs by offering clinical data on patients which is the basis for the management of medical and nursing interventions/conduct.

Table 3 shows that the result corresponding to the deepening of knowledge regarding the participation of nursing professionals in the SOP training was statistically significant, as well as the result derived from the comparison between the performance of interventions after the SOP and their use in daily practice by the professionals studied.

Table 4 shows that $202(81.8 \%)$ professionals indicated patient safety as a potentiality observed following implantation of SOP from the institution's point of view. The same aspect 
Table 4 - Frequency and percentage of responses in relation to the potentialities observed from implementation of the Standard Operational Protocols associated with the institution, professionals and Standard Operational Protocols, Ribeirão Preto, São Paulo, Brazil, 2015

\begin{tabular}{lcc}
\multicolumn{1}{c}{ Potentialities } & $\mathbf{n}$ & \% \\
\hline Institution & 202 & 81.8 \\
Patient safety & 194 & 78.5 \\
Professional safety & 154 & 62.3 \\
Standardization of materials used & 153 & 61.9 \\
Commitment to continuing education & 90 & 36.4 \\
Managerial safety & 86 & 34.8 \\
Availability of materials & 2 & 0.8 \\
Improvement in the quality of work & & \\
Professional & 195 & 78.9 \\
Safety in the development of interventions & 190 & 76.9 \\
Clear responsibility of those who must carry out the intervention & 178 & 72.1 \\
Patient safety & 151 & 61.1 \\
Professional valorization through continuing education & 123 & 49.8 \\
Patient orientation based on institution documents & & \\
SOP & 190 & 76.9 \\
Updated procedures & 163 & 66 \\
Easily understood & 140 & 56.7 \\
Easy access & 3 & 1.6 \\
Did not answer & & \\
\hline
\end{tabular}

Note: SOP - Standard Operational Protocols

Table 5 - Frequency and percentage of responses regarding the weaknesses observed from the implantation of the Standard Operational Protocols associated with the institution, professionals and the Standard Operational Protocols, Ribeirão Preto, São Paulo, Brasil, 2015

\begin{tabular}{lcc}
\hline \multicolumn{1}{c}{ Weaknesses } & $\mathbf{n}$ & \% \\
\hline Institution & 113 & 45.7 \\
Reduced number of professionals & 107 & 43.3 \\
Absence or inadequacy of physical space & 84 & 34.0 \\
Absence of materials & 34 & 13.8 \\
Insufficient training to carry out interventions & 27 & 10.9 \\
Difficulty in accessing SOPs in the service & & \\
Others & 2 & 0.8 \\
Train the professionals outside the units & 2 & 0.8 \\
Poor quality material & 1 & 0.4 \\
Train newly-admitted professionals & 1 & 0.4 \\
Absence of professionals in the evaluation of materials & & \\
Professional & 91 & 36.8 \\
Lack of time to consult SOPs & 52 & 21.1 \\
Non-recognition of SOPs as an institution protocol & 7 & 2.8 \\
Non-understanding of the interventions proposed in the MAGP & & \\
Others & 2 & 0.8 \\
Newly-admitted untrained professional & 1 & 0.4 \\
Limitation of techniques to nurses & 1 & 0.4 \\
Lack of professional interest & 1 & 0.4 \\
Absence of professionals in the evaluation of materials & & \\
SOP & 78 & 31.6 \\
Failure to update SOPs & 37 & 15.0 \\
Absence of catalog folder with SOPs in the health unit & 5 & 2.0 \\
Difficult to understand & & \\
Others & 2 & 0.8 \\
No periodical training is available & 6 & 0.4 \\
Disagree with Protocols & 2.4 \\
Did not answer & & \\
\hline
\end{tabular}

Note: SOP - Standard Operational Protocols was stated by 178 workers $(72.1 \%)$ as potentiality for the professional. Corroborating this finding, the most frequent data regarding the "professional" corresponded to safety in the performing interventions $(78.9 \%)$ and to the clarity with which the professional is responsible for carrying out the intervention $(76.9 \%)$. Regarding SOP, the highlighted potentialities were "updated procedures" $(76.9 \%)$ and "easy to understand" (66\%).

In relation to the institution, the subjects of the research pointed out the reduced number of professionals $(45 \%)$, is the main weakness which makes it difficult to perform the interventions, besides the inadequate physical space $(43.3 \%)$. Regarding professionals, the weaknesses pointed out are due to the lack of time to consult SOPs $(36.8 \%)$. The lack of updating the operational protocols was another weakness $(31.6 \%)$, demonstrating the commitment of professionals with the correct execution of interventions.

\section{DISCUSSION}

Protocol-based care is seen as a mechanism to facilitate professional nursing practice and to standardize care provided ${ }^{(13)}$. In this sense, it should be emphasized that the panorama presented by non-participants in the SOPs training reflects the importance of post-implantation evaluation. Even though the training took place in loco, it did not guarantee the participation of all professionals, especially because it occurred at specific times, thereby requiring effort to meet this requirement. The educational process should not be understood as an exercise in punctuality, but as a continuous action; a fact that did not occur in this reality.

Education proposals should take into account processes that offer continuity, since even though they have succeeded in incorporated knowledge and changes in conduct, it is recognized that the results achieved could be strengthened by adopting the strategy of Permanent Education in Health $(\mathrm{PEH})$ especially because this enables education to occur on 
an ongoing basis. There is no way other than by education, since it promotes the transformations, the necessary changes and always with the objective of ensuring rights, improving the quality of care and minimizing risks for the patient ${ }^{(14-15)}$. The SOPs training must be contextualized in the $\mathrm{PEH}$, which proposes to transcend technicality and punctual skills, instigating the active participation of learners ${ }^{(16-17)}$. Consequently, because the nursing staff constitutes a greater percentage of professionals within the health team, nurses have a decisive role in the quality of service provided.

$\mathrm{PEH}$ together with the Evidence Based Practice (EBP) and the incorporation of standardized language can guarantee a better quality of care for clients and better visibility of the profession by demonstrating the scientific basis for care ${ }^{(9)}$. PEH provides nursing professionals with a qualified and professional development, thus valorizing the nursing category. It is reiterated that improvement and updating, with a view to optimizing the care provided, should be part of a permanent educational process ${ }^{(18)}$, leading to the safety of professionals who are motivated to use SOPs more frequently. In addition, managers should provide nursing professionals with continuing education opportunities to help them perform patient-centered care within a perspective of efficiency ${ }^{(19)}$.

Nurses have a relevant role in $\mathrm{PEH}$, and should stimulate and provide an environment conducive to discussion and clarification of the issues arising daily. This function is related to the concept of process described by Donabedian ${ }^{(10)}$, and widely discussed in a Brazilian study ${ }^{(20)}$ that underscores the process component as the provision of assistance according to technical-scientific standards established and accepted in the scientific community on a certain subject, and the use of resources in their quantitative-qualitative aspects. This component becomes more relevant when faced with the data presented in Tables 1 and 3. These reveal that nurses are the professionals with the lowest frequency of responses regarding the non-use of SOPs in the last 12 months and with considerable frequency in daily use. Additionally, in general terms, they account for the percentages for deepening of knowledge and the interventions that began to take place after implementation of the SOPs.

All the changes related to performance in compliance with the interventions do not have a broad process of supervision, and this managerial tool is understood to be responsible for promoting reflection and discussion about work practices based on the monitoring of daily tasks, thereby making it possible to identify the needs of the team and to act in the diffusion of the educational process so that the development of the interventions is carried out in a correct and safe way, thus minimizing the possibility of errors ${ }^{(21)}$.

Regarding the interventions, many began to be carried out in the basic health units, for example late and relief catheterization, among others. It should be noted that, prior to the implementation of the SOPs, the vast majority of interventions were carried out in the DBHUs, generating an increase in the demand in these units, and it was possible to develop them in the BHUs, provided the necessary material and physical resources were provided.

This perspective refers to the resultant component according to the benchmark used in this study ${ }^{(10)}$, since the implementation of these operational protocols had a positive effect, considering that patients do not need to be moved to a unit of greater technological complexity simply for the execution of an intervention. According to the Ministry of Health ${ }^{(22)}$, interventions can and should be carried out by the teams that work in the BHUs in order to avoid bottlenecks in the services at other levels of care and thereby contribute to an increase in resolutivity.

Thus, in allusion to the evaluation of results established in the Donabedian model ${ }^{(10)}$ and also described by Brazilian authors $^{(20)}$, the incorporation and subsequent execution of the SOPs revealed implications regarding the clinical competence of nursing professionals, patient safety standards, managerial safety and improvement in the quality of services, thus generating quality care and client satisfaction.

Nursing professionals, after SOPs training, have identified that the institution is concerned with patient safety, becoming an extremely favorable environment for establishing a safety culture by the manager through strategies capable of eliminating or reducing barriers to the implementation of actions that ensure patient safety ${ }^{(2,23)}$. Corroborating the fact that the adoption of protocols promotes patient safety, a study carried out in a hospital of high complexity in southern Mato Grosso, demonstrated that the implementation of the protocol regarding infection of the urinary tract in the intensive care units presented a negative linear correlation with the reduction of cases of urinary tract infection in the course of the months; thus favoring safer care ${ }^{(7)}$.

Regarding the materials, it was evident that the standardization was positive; the availability however, must be guaranteed, since, in order to be able to carry out any intervention, it is necessary to provide material resources in appropriate quality and quantity. The shortage of material resources coupled with the need to provide mandatory and preferably quality service are the daily challenges faced by health institutions in Brazil and in the world as a whole ${ }^{(24)}$. In accordance with the adopted framework ${ }^{(10)}$, the importance of the structural preparation of the health units is highlighted, with emphasis on the need to adapt the facilities in terms of organization and resources for the development of interventions in the daily practice of nursing professionals.

A study carried out on losses due to the inadequacy of the physical structure reported that, from the client's perspective, there may be a reduction in access, resolution, humanization and non-provision of certain actions. While for the health professional, this can generate impairment of their autonomy, dissatisfaction, fatigue and improvisations, conflicts with users and difficulty in their performance and providing quality practices. Furthermore, if this is associated with the lack of certain materials, it can greatly compromise the execution of the interventions to the detriment of patient safety ${ }^{(25)}$.

The professionals distinguished as weaknesses aspects related to the structure, demonstrating the need for greater attention with the management of people and with the availability of materials, as well as improving and/or maintaining the physical infrastructure, since these factors will certainly have a direct influence on patient care, as described by Donabedian ${ }^{(10)}$.

The question of human resources, pointed to as one of the weaknesses, is a complex and important factor, also related to the lack of time to consult SOPs. It should be noted that in a 
reality with tight shifts, associated to absenteeism, the losses stand out, especially when it refers to the quality of care provided by nurses ${ }^{(26)}$. The nurse is responsible for establishing the professional staff; However, in most services, they have no autonomy in the hiring process. This professional should be guided by Cofen [Federal Nursing Council] Resolution 293/2004, which establishes and sets the parameters for the nursing staff dimensioning in the care units, in order to guarantee the safety and quality of care for the client ${ }^{(27)}$.

These notes corroborate the health care quality evaluation model, according to which each component of the triad (Structure, Process, Outcome) is influenced by its precursor, implying the interdependence of its elements ${ }^{(10-11)}$.

\section{Limitations of the study and contributions to Nursing}

It should be pointed out that the study had as a limitation the fact that among the 51 Health Units, Samu and administrative sectors in the MHS of a municipality in São Paulo, only 37 units returned the questionnaires in a timely manner for participation in the research, thereby obtaining a total of 247 respondents. However this limitation does not detract from the importance of the study, since the results found contribute to assert the importance of the care provided to the patient with quality and safety. As such, the nursing protocols are essential and aim to incorporate new knowledge and procedures to nursing practice, besides enabling objectivity, agility, quality and greater security to the client, the professional and the service.

\section{CONCLUSION}

According to the results found in the study and based on the health service evaluation framework, weaknesses related to the "Structure" were found, evidenced by the need for greater attention with the management of people and the availability of materials, as well as of improvement and/or maintenance of the physical infrastructure, since these are factors that will certainly influence directly in the nursing care.

In relation to the "Process", it was found that the adoption of the protocols on a daily basis was a positive component, which generated a standardized service delivery and in accordance with technical-scientific parameters established and accepted by the scientific community.

Regarding the "Outcome", it was observed that this aspect was detected in the scope of the decreased demand in the DBHUs. In addition, the clinical competence of nursing professionals in meeting patient safety standards, the safety of the manager and the improvement of the quality of the service, which involved quality care and therefore client satisfaction, were highlighted.

The need for a reassessment of essential educational actions to ensure SOPs are widely used was identified. It should be noted, however, that there was potentiality originating from the SOPs training, albeit limited to those who were working in the units at the time. This educational action may have led to the improvement of the quality of care provided by nursing, since a change was detected in the way interventions were performed together with a deepening of knowledge, as well as an increase in the range of services/interventions offered by the health units. Nevertheless, the results could have been enhanced if the PEH strategy was adopted, which aims to transform the practice through a continuous educational process established in the daily work practices.

The evaluation of the use of SOPs adopted in the Municipal Secretariat made it possible to identify and analyze the weaknesses and potentialities that will favor the revision of the strategy used to face the difficulties presented, as well as the maintenance of those that contributed to qualify the assistance provided to the user and strengthen the practices of nursing. In addition, it is suggested that new studies be developed to ensure the quality of care and propose the necessary changes.

\section{REFERENCES}

1. Brasil. Ministério da Saúde. Secretaria de Atenção à Saúde. Departamento de Atenção Básica. Programa Nacional de Melhoria do Acesso e da Qualidade da Atenção Básica (PMAQ): manual instrutivo [Internet]. Brasília: Ministério da Saúde; 2012 [cited 2016 Sep 24]. 62 p. Available from: http://189.28.128.100/dab/docs/publicacoes/geral/manual_instrutivo_pmaq_site.pdf

2. Simões e Silva C, Gabriel CS, Bernardes A, Évora YDM. Opinião do enfermeiro sobre indicadores que avaliam a qualidade na assistência de enfermagem. Rev Gaúcha Enferm [Internet]. 2009 [cited 2016 Sep 24];30(2):263. Available from: http://seer.ufrgs. br/RevistaGauchadeEnfermagem/article/view/7586

3. Honório RPP, Caetano JA. Elaboração de um protocolo de assistência de enfermagem ao paciente hematológico: relato de experiência. Rev Eletr Enf [Internet]. 2009 [cited 2017 Feb 21];11(1):188-93. Available from: http://www.fen.ufg.br/revista/v11/ $\mathrm{n} 1 / \mathrm{v} 11 \mathrm{n} 1 \mathrm{a} 24 . \mathrm{htm}$

4. Almeida ML, Segui MLH, Maftum MA, Labronici LM, Peres AM. Instrumentos gerenciais utilizados na tomada de decisão do enfermeiro no contexto hospitalar. Texto Contexto Enferm [Internet]. 2011 [cited 2016 Sep 24];20(spe):131-7. Available from: http://www.scielo.br/pdf/tce/v20nspe/v20nspea17.pdf

5. Viana DG, Cabanas A, Antón LMTB. Proposta de protocolo para uso de EPI em UBS. Rev Eletrônica Enferm do Val do Paraíba [Internet]. 2012 [cited 2017 Feb 21];1(2):37-59. Available from: http://publicacoes.fatea.br/index.php/reenvap/article/ view/557/390

6. Uña Cidón E, Cuadrillero Martín F, Hijas Villaizán M, López Lara F. A pilot study of satisfaction in oncology nursing care: an indirect predictor of quality of care. Int J Health Care Qual Assur [Internet]. 2012 [cited 2016 Sep 24];25(2):106-17. Available 
from: http://www.emeraldinsight.com/doi/abs/10.1108/09526861211198272

7. Miranda AL, Oliveira ALL, Nacer DT, Aguiar CAM. Resultados da implementação de um protocolo sobre a incidência de Infecção do Trato Urinário em Unidade de Terapia Intensiva. Rev Latino-Am Enferm [Internet]. 2016 [cited 2017 Feb 21];24:e2804. Available from: http://www.scielo.br/pdf/rlae/v24/pt_0104-1169-rlae-24-02804.pdf

8. Olivo VF, Portela OT, Dalla LL. Gerenciamento do processo de trabalho em enfermagem: um estudo diagnóstico para subsidiar a instituição de padrões de qualidade no serviço hospitalar. Bibl Lascasas [Internet]. 2013 [cited 2017 Feb 21];9(1). Available from: http://www.index-f.com/lascasas/documentos/lc0686.pdf

9. Oliveira ARS, Carvalho EC, Rossi LA. From The Principles of Practice to The Nursing Outcomes Classification: perspectives on care strategies. Ciênc Cuid Saúde [Internet]. 2015 [cited 2016 Sep 24];14(1):986-92. Available from: http://www.periodicos.uem. br/ojs/index.php/CiencCuidSaude/article/view/22034/14208

10. Donabedian A. The quality of medical care. Science [Internet]. 1978 [cited 2016 Sep 24];200(4344):856-64. Available from: http://www.ncbi.nlm.nih.gov/pubmed/417400

11. Ayanian JZ, Markel H. Donabedian's Lasting Framework for Health Care Quality. N Engl J Med [Internet]. 2016 [cited 2016 Oct 10];375(3):205-7. Available from: http://www.nejm.org/doi/10.1056/NEJMp1605101

12. Hartz ZMA. Avaliação em saúde: dos modelos conceituais à prática na análise da implementação de programas [Internet]. Rio de Janeiro: Fiocruz; 1997 [cited 2016 Sep 24]. 132 p. Available from: http://static.scielo.org/scielobooks/3zcft/pdf/hartz-9788575414033.pdf

13. Rycroft-Malone J, Fontenla M, Bick D, Seers K. Protocol-based care: impact on roles and service delivery. J Eval Clin Pract [Internet]. 2008 [cited 2016 Oct 15];14(5):867-73. Available from: http://doi.wiley.com/10.1111/j.1365-2753.2008.01015.x

14. Oliveira JSA, Cavalcante EFO, Macêdo MLAF, Martini JG, Backes VMS. Practice of permanent education by nursing care in health services. J Nurs UFPE line [Internet]. 2013 [cited 2016 Oct 15];7(2):598-607. Available from: http://www.revista.ufpe.br/ revistaenfermagem/index.php/revista/article/view/3073/pdf_2088

15. Duarte MLC, Oliveira AI. Compreensão dos coordenadores de serviços de saúde sobre educação permanente. Cogitare Enferm [Internet]. 2012 [cited 2016 Sep 24];17(3):506-12. Available from: http://revistas.ufpr.br/cogitare/article/view/29292

16. Fermo VC, Radünz V, Rosa LM, Marinho MM. Patient safety culture in a bone marrow transplantation unit. Rev Bras Enferm [Internet]. 2015 [cited 2016 Sep 24];68(6):1139-46. Available from: http://www.scielo.br/pdf/reben/v68n6/en_0034-7167-reben-68-06-1139.pdf

17. Sardinha PL, Cuzatis LG, Dutra TC, Tavares CMM, Dantas ACC, Antunes EC. Educação permanente, continuada e em serviço: desvendando seus conceitos. Enfermería Glob [Internet]. 2013 [cited 2016 Sep 24];12(29):324-40. Available from: http://scielo. isciii.es/pdf/eg/v12n29/pt_revision1.pdf

18. Viana DS, Viana DMS, Nogueira CA, Araújo RS, Vieira RM, Rennó HMS, et al. A educação permanente em saúde na perspectiva do enfermeiro na estratégia de saúde da família. Rev Enferm do Centro-Oeste Min [Internet]. 2015 [cited 2016 Sep 24];5(2):165868. Available from: http://www.seer.ufsj.edu.br/index.php/recom/article/view/470

19. Fox MT, Butler JI. Nurses' perspectives on how operational leaders influence function-focused care for hospitalised older people. J Nurs Manag [Internet]. 2016 [cited 2016 Oct 8]; Available from: http://doi.wiley.com/10.1111/jonm.12421

20. D'Innocenzo M, Adami NP, Cunha ICKO. O movimento pela qualidade nos serviços de saúde e enfermagem. Rev Bras Enferm [Internet]. 2006 [cited 2017 Feb 21];59(1):84-8. Available from: http://www.scielo.br/pdf/reben/v59n1/a16v59n1.pdf

21. Santos JLG, Lima MADS. Gerenciamento do cuidado: ações dos enfermeiros em um serviço hospitalar de emergência. Rev Gaúcha Enferm [Internet]. 2011 [cited 2016 Sep 24];32(4):695-702. Available from: http://www.scielo.br/pdf/rgenf/v32n4/v32n4a09.pdf

22. Brasil. Ministério da Saúde. Secretaria de Atenção à Saúde. Departamento de Atenção Básica. Procedimentos [Internet]. Brasília: Ministério da Saúde; 2011 [cited 2016 Oct 15]. 64 p. Available from: http://189.28.128.100/dab/docs/publicacoes/cadernos_ab/ abcad30.pdf

23. Nunes FDO, Barros LAA, Azevedo RM, Paiva SS. Segurança do paciente: como a enfermagem vem contribuindo para a questão? Rev pesqui Cuid fundam [Internet]. 2014 [cited 2016 Sep 24];6(2):841-7. Available from: http://www.seer.unirio.br/index.php/ cuidadofundamental/article/viewFile/3007/pdf_1297

24. Politelo L, Rigo VP, Hein N. Eficiência da Aplicação de Recursos no Atendimento do Sistema Único de Saúde (SUS) nas Cidades de Santa Catarina. Rev Gestão em Sist Saúde [Internet]. 2014 [cited 2016 Sep 24];3(2):45-60. Available from: http://www.revistargss. org.br/ojs/index.php/rgss/article/view/105

25. Pedrosa ICF, Corrêa ÁCP, Mandú ENT. Influências da infraestrutura de centros de saúde nas práticas profissionais: percepções de enfermeiros. Ciência, Cuid e Saúde [Internet]. 2011 [cited 2016 Sep 24];10(1):058-65. Available from: http://periodicos.uem.br/ ojs/index.php/CiencCuidSaude/article/view/13288

26. Sancinetti TR, Soares AVN, Lima AFC, Santos NC, Melleiro MM, Fugulin FMT, et al. Nursing staff absenteeism rates as a personnel management indicator. Rev da Esc Enferm da USP [Internet]. 2011 [cited 2016 Sep 24];45(4):998-1002. Available from: http:// www.scielo.br/pdf/reeusp/v45n4/en_v45n4a31.pdf

27. Conselho Federal de Enfermagem. Resolução COFEN n 293, de 21 de setembro de 2004. Fixa e estabelece parâmetros para dimensionamento do quadro de profissionais de enfermagem nas unidades assistenciais das instituições de saúde e assemelhados [Internet]. 2004 [cited 2016 Sep 24]. Available from: http://www.portalcoren-rs.gov.br/web/resoluca/r293.htm 
28. Conselho Regional de Enfermagem de Goiás. Protocolo de Enfermagem na Atenção Primária à Saúde do Estado de Goiás [Internet]. Goiânia: Conselho Regional de Enfermagem de Goiás; 2014 [cited 2016 Oct 15]. 336 p. Available from: http://www.corengo.org. br/wp-content/uploads/2015/02/Protocolo-de-Enfermagem-2015.pdf 